\title{
A TAXPAYER'S CHOICE INCENTIVE SYSTEM: AN EXPERIMENTAL APPROACH TO COMMUNITY ECONOMIC DEVELOPMENT TAX INCENTIVES
}

\author{
ROBERT S. RoBIN*'
}

I

\section{The Tax Incentive Device in the Poverty Context}

There is currently no reliable evidence of the value or the cost of any community economic development tax incentive, and because of this, it seems preferable to experiment with broadly applicable tax devices before enacting or even proposing legislation. Any one-track tax incentive system which benefits only a narrow band of businesses will not produce a wide reception among those whose diverse needs are not covered by it. ${ }^{1}$ Broad participation in an actual or simulated program can be obtained, however, under a tax incentive system which, within an overall limit, permits individual businesses to select a mixture of tax benefits which matches the demands of the operation involved. A multi-track, taxpayer-choice incentive system may become more narrow as facts are developed relating to taxpayer-use frequency, economic results, and government costs, but breadth and scope are needed initially in any experimental system to induce use of it. Actual simulation of highly experimental tax incentives is one way to create businesses and jobs in ghettos. And it is the only way to produce evidence of which tax incentives, if any, helped or hindered the effort.

One factor which forces experimentation rather than legislation is the realization that no one, in or out of government, can develop a factual case supporting the value or the cost of any poverty area tax incentive. Community.economic development tax incentives are a new, strange, and misunderstood phenomenon. No one really knows what to expect of them because they have never been used in this country before. ${ }^{2}$ Indeed, such incentives must draw business into ghettos in the first place, a task not normally assigned to such devices. ${ }^{3}$ Because these kinds of incentives

- [The author, one of the draftsmen of the tax sections of the Community Self-Determination Act of $\mathrm{x}_{968}$, is engaged in the private practice of law in Chicago.-Ed.]

${ }^{1}$ Part II of this article provides an example of how a one-channel tax incentive system can provide significant tax benefits but illustrates that these are available only to a taxpayer willing to sell his facility to a community corporation. Such a program dictates the types of businesses to be provided to ghettos and the methods of providing them and is precisely the type of narrow program to be avoided.

${ }^{2}$ Such tax incentives have been used extensively by numerous developing nations overseas. See Robin, Developing Nations Eager for U.S. Investors, J. Commerce, March 2, I964. Some principles of foreign economic development tax incentives were utilized in the preparation of the tax incentives diseussed here and those which were part of the Community Self-Determination Act of 1968 .

"Several companies, such as IBM, Eastman Kodak, and Mattel Toys, have tried ghetto operations in the past two or three years. However, the ghetto operations of some companies have special support in terms of loans, guarantees, out-put contracts, and gifts of senior managerial talent. The creation and continued sponsorship of such ghetto operations, although laudible, cannot be regarded as motivated by normal hard-nosed business considerations. 
are new and strange, there is considerable difficulty in thinking clearly about them, and this is the reason why no one, especially in government, can produce enough of an illusion of certainty about their effect and their cost to justify proposing a definite incentive program to Congress.

Rather than wasting another three years waiting for nothing to happen, ${ }^{4}$ it is time to recognize that the government has three choices with respect to poverty area tax incentives: (a) it can forget about them; $(b)$ it can recognize that no one has the evidence necessary to soundly predict the value to the taxpayer or the cost to the government of any incentive, but ask for tax legislation anyway (and let all parties wink at the absence of facts); or $(c)$ it can recognize that no one has the facts and say so, but proceed with a more pragmatic search for a solution through tax legislation simulation. The purpose of this article is to explore this last alternative.

This new approach should include a realization that the purpose of any incentive is to change a taxpayer's mind about the financial attractiveness of a particular activity. Thus, it is necessary to discover what risks bother him, and to attempt to quantify those risks as he would. Instead of asking for tax legislation without examining what incentive might induce a change of mind, the government should actually simulate the incentives by cash payments which allow each cooperating taxpayer to choose the incentives he thinks best for him. This approach should provide a basis for determining which tax incentives, if any, provide the necessary conditions and inducements to persuade a businessman to bring his capital, know-how, and jobs to the poor. Then, if an incentive, or a group of them, actually produced desired action at a sensible cost, legislation should be proposed. Evidence of the workability of the incentive should be convincing to Congress.

The first step toward clearing up present misunderstandings is to start over again and ask the right questions. The traditional governmental approach to economic development tax incentives by-passes the right questions about taxpayer motivation and substitutes assumptions instead. The doctrinaire government tax specialist, a "hard line Revenuer," unencumbered by the facts as he is, adopts the silent assumption that any tax incentive automatically provides a taxpayer with a sufficiently increased chance for profit to justify his acceptance of any and all other risks, whatever they may be. With that proposition firmly established (resting, as it does, on "all taxpayers are crybabies" theory), our man in Washington further assumes the maximum use of the incentive by the broadest class of potentially eligible taxpayers (which in our case means every sizeable business in the country plus a few nasty promoters. Reliance on these unstated perceptions causes planners to miss completely the issue of taxpayer motivation. Moreover, these perceptions result in an overstatement of the cost of poverty area tax incentives to the government. It is especially unfortunate that reliance on an unspoken faulty assumption not only smothers the problem, but also loads the answer to the wrong question.

\footnotetext{
"Nothing has been proposed since August, 1968.
} 
These assumptions do not surface in the intense discussions, in and out of government, relating to tax incentives. But the term "cost effectiveness" always does. The phrase "cost effectiveness" is designed to raise the issue of whether the government will receive what it regards as effective action in exchange for the loss of tax revenues resulting from enactment of a particular incentive. Calculation of the loss of tax revenues must be based on some judgment of how much less money taxpayers will be paying because of their use of a tax incentive. Sometimes this issue is analyzed. Often it is not. Often it does not have to be. In business operations in which the Treasury or the Internal Revenue Service has years of experience, a sensible estimate of the dollar amount of noncollected taxes resulting from the use of an incentive by taxpayers can be made. However, in the unexplored area of private sector ghetto operations, no one, in or out of government, can provide real evidence of which tax incentives will be accepted and used. Indeed, no one knows for sure what the extra risks will be, and a fortiori, no one can determine the costs to be cut (by whatever legislative mechanic) in order to provide the possibility of a profit. Because these answers are unavailable, the right question, at this stage, is not and cannot be "cost effectiveness." The right questions are whether and to what extent tax incentives will be used by taxpayers.

In order to forecast the dollar cost of those tax incentives which will encourage a taxpayer to act, one must understand why a taxpayer is not now acting. Government must understand the risks perceived by business if government is to exercise effectively its power to (I) reduce risks or (2) trade tax benefits for acceptance of unmeasurable risks. Government action, whether by legislation or experimental simulation, is useless if it does not deal directly with the pitfalls which businessmen actually see or think they see in the undertaking of an untried and unwanted project.

It must be accepted that the taxpayer for whom the incentives are to be designed presently sees very little business reason for locating his plant in the ghetto or for hiring the untrained. The raw economics of running most profitable businesses simply does not justify ghetto operations. A plant put in a ghetto is subject to more risks than one located elsewhere. Employment of a large group of the hard-core unemployed is thought to subject a business to more risks and costs than it faced previously. And as of now, such increased risks are not matched by the possibility of profit. Moreover, several of the substantial risks are not of a business nature and, thus, are harder to measure. This means that the corporate and professional experts who specialize in risk measurement and profit potential projections are not equipped with the skills or experience required to forecast a dollar exposure or profit return on a ghetto investment. When a corporate board of directors reviews any business plan, it is the risks which they see. Thus, when a ghetto business plan is reviewed, a board will want to know its risk potential. What will be obvious to the board and what will cripple any chance of approval of a scheme is the absence of a dollar exposure forecast based on experience. To such a board, approval of a ghetto 
business or employment plan would be tantamount to signing a blank check. No businessman will do this. Businessmen want as much certainty as possible. They will take risks if they can measure those risks. But they will not spend money-even if they will get part of it back from the government-without some idea of whether the spending will produce profits.

Although incentives can be created to meet a variety of circumstances, the perceived risks which presently inhibit action by the private sector in the poverty area seem to be common to most types of businesses. A businessman, in the privacy of his own office, might analyze the risks he sees or thinks he sees this way:

"I. If I put hard-core employees in my plant, I must set up, and pay for, special facilities to train them. I can get all the workers I need now to perform the functions which the hard-core employees might be able to perform after training, so I see no reason to spend the extra money to assure myself of a supply of employees I don't presently require.

"2. By introducing such a group of employees into my plant, I risk the hostility of other employees on all levels. I create labor union representation problems, and, at worst, I may be confronted with protection and violence problems.

" 3 . If I put my plant in a ghetto, there is the risk that it will be burned down or become a pawn in a political or social dispute. The issues which can trigger such events are not business issues and thus I have no control over them nor do I have any expertise in my organization to deal with them. I cannot buy insurance to cover any such catastrophy. I don't want the publicity which would derive from such a situation or the controversy leading up to it. And besides all of that, there is no business reason for my plant to be in the ghetto in the first place.

"4. If, despite all the foregoing problems, I would still be willing to undertake such tasks, I cannot get anyone in my already thinned-out middle management level to take charge of a training program or a ghetto plant because he will feel he is sidetracked from his main career, which is moving up in the mainstream of this company.

"5. I can discharge my responsibilities to the poor with much more facility and with no intereference in the operation of my business by making a charitable contribution to some foundation which does what it can. This will enable me to say 'I gave at the office."

Can fiscal incentives be developed to overcome these risks and difficulties which the taxpayer sees as inherent in transferring jobs, facilities, and know-how to an underdeveloped community? They can be, if initially we understand the substance of tax incentives, the necessity for a system of incentives (and why one or two big ones won't work), and the manner in which a taxpayer looks at an incentive package. With this understanding, one will conclude that there are a lot of different ways to get the job done.

When the technical convolutions of the tax code are stripped away, it appears 
that there are only two types of tax "breaks" available: tax deferral or tax forgiveness. Tax deferral means that the taxpayer pays the same amount of tax he otherwise would have to pay, but the payment of all or part of the tax is postponed until a future time. The time to which payment is postponed is supposedly tied to an event which will produce cash, thus making it easier to pay. That event is usually the sale of something which presumably will produce cash to pay the taxes which, but for the incentive, should have been paid earlier. The event which triggers the payment of postponed tax can be almost anything. It can even be some date in the future at which nothing actually happens, but by which time something might have happened. In other situations, the event is merely the passing of a determinable period. Tax forgiveness, on the other hand, is just that; the taxpayer is relieved of an obligation to pay particular taxes.

Of course, it is not all that easy. Tax deferral or tax forgiveness or a combination of the two principal tax incentives are always set in a complex structure of technical requirements designed to limit the cases to which the incentive can apply and thereby prevent abuses. It is with respect to these technical rules that a draftsman has great flexibility to tune and tinker the tax incentives to accomplish his objectives and to minimize the risks perceived by the taxpayer.

What kinds of tax incentives can produce the desired action? The answer to this question requires consideration of the twin issues of how large a single incentive must be to motivate taxpayer action and whether an incentive of the requisite size is too large to be passed by Congress. For example, there has been much talk of a tax credit (partial tax forgiveness) which is geared to wages paid by companies to train undereducated employees. The credit stops when employees reach the level at which they can function on the production line, whenever that is. The cost of the extra training is said to be about $\$ 3,000$ per hard-core unemployed worker. Further, the turnover rate is said to be $50 \%$ higher than normal for hard-core factory labor. As discussed in detail later, extra costs over the first three years of extra training and recruitment for a 120 man work force, half of whom are hard-core unemployed, is $\$ 396,000$. A $10 \%$ tax credit yields an actual annual cash savings of $\$ 39,600$. This is hardly enough to motivate management to set up a program which trains workers they think they can do without and which exposes the company to extra risks which it feels it cannot handle. A tax credit of significantly more than $10 \%$, by itself, would hardly have a chance of becoming law. And a tax credit of 10\% (even one which does not distinguish between training and productive time and which thus eliminates the inevitable Internal Revenue Service bargaining audit) would not be used by a taxpayer because-it is not big enough. Thus, dead ends will always exist at both the enactment level and the taxpayer-use level if single tax incentives, even good ones, are considered by themselves. These impediments are avoided by a tax incentives package which has a chance of both being enacted and being used. 
Development of a tax incentive system for actual use will mean that a taxpayer also has some work to do. He must guess as to the likelihood of the occurrence of events which trigger tax savings, identify and quantify extra risks, add up his extra costs resulting from extra risks, compare the profit producable by those costs to the extra tax savings, isolate the nonbusiness open-ended exposures, and see if it all makes sense. The fact that he will have to make all these judgments and assume the risk of the occurrence of tax-significant events will not stop him. Indeed, this is the basis of all tax planning. For example, if a taxpayer buys a building and takes accelerated depreciation, he knows now that at a particular point in the future, the depreciation deduction will run out and his cash flow costs will increase because, at that future time, he will have used up his depreciation allowance. He knows that he will have to sell the building nine or ten years from now or start investing cash to make up for the tax benefits which have run out. Or, he will have to buy another building and take fast depreciation on it to make up for the loss of depreciation on the first building he bought. At the time he undertakes the plan, he knows that he is on the depreciation treadmill and that the whole structure will fall apart if he does not buy a second building or sell the first one in time. Thus, an analysis involving prediction of facts and events in order to analyze a tax package is nothing new. This is precisely how sophisticated taxpayers think. This is the way tax incentives should be created because this is the way tax incentives will be used, if used at all.

II

How a Taxpayer Quantifies Risks and Determines the Value of Tax Incentives Designed to Share Those Risks

In I968, the Community Self-Determination Act was jointly introduced in the House and Senate. 5 Buried in that legislation was a set of tax incentives, part of which applied to community corporations and part of which applied to outside companies. The outside company was the established business which had jobs to give, had a plant to locate in the ghetto, had the know-how to do both, and of equal importance, had the experts who could try to advise it of the consequences. The policy decision behind the Act was that the outside company should set up the plant, provide the training and the jobs, and then sell the plant to a community corporation which was to be a "neighborhood conglomerate" designed eventually to own businesses. The Act set up this institutional acquiring entity owned by the "people," provided funds to make such acquisitions possible, and gave the outside company a package of tax incentives which would offset all the risks if the plant were successful and if the plant were actually sold. The key tax breaks, those which would provide most of the cash to make the outside company whole and give it a profit on its risky investment, were tied to the sale of the plant.

\footnotetext{
${ }^{6}$ S. 3875, goth Cong., $2 d$ Sess. (1968).
} 
Naturally, a complex statutory "infrastructure" was thought to be required to make this program work: (I) each poor man was to own a piece of all the companies eventually purchased-hence the "community corporation"; (2) the poor were to be provided enough money to buy the plants-hence "community economic development banks" and nationwide government guaranteed bond issues; and (3) with all this money and power, measures were to be taken to prevent abuses-hence ninety per cent of the Act. Enactment of the whole institutional framework seems unlikely, at least for now. However, some of the tax incentives designed to benefit the outside company will be considered here because the program illustrates how a taxpayer assesses the value of an untried tax package in an unexplored area of business activity.

In order to quantify the risks perceived by the taxpayer and, at the same time, examine tax mechanics designed to share some of those risks, this section of the artcile will examine the actual dollar impact of the incentives on the taxpayer for the purpose of determining how he will fare if he enters the poverty business. Also considered is the issue of whether a tax incentive program in which the tax break is tied to the sale of a successful business will work without an elaborate "infrastructure." In part III of this article, the focus is whether there are events other than the sale of a business to which tax benefits can be tied in order to attract taxpayers who are not willing to sell their plants.

Assessment of the dollar impact of a tax incentive package which contemplates eventual sale of a facility to a poor community necessitates a discussion of several interrelated tax benefits, which, although individually insufficient, produce a substantial return in the aggregate. The tax program of the Community Self-Determination Act, stripped of much of its infrastructure, sets up these incentives:

I. Physical plant facilities will be permitted rapid tax amortization depending upon the degree to which the community is underdeveloped. If some development index indicates that the community is at the maximum level of economic underdevelopment, physical facilties including real estate may be amortized in as short a time as thirty-six months.

2. The old investment tax credit relating to certain machinery and equipment will be resurrected. There will, however, be no tax credit recapture upon the sale of a facility to a "community group."

3. An additional tax credit, called the human investment tax credit, will be. available in an amount equal to ten per cent of the wages and salaries paid by the taxpayer to employees. No distinction is to be drawn between training and production activities of such employees for purposes of utilizing this credit.

4. The profits received by the taxpayer upon the sale of a factility to the "community" are normally subject to a capital gain tax. Such capital gains tax would not then be payable so long as and to the extent the proceeds of the sale are reinvested in another similar operation or in low interest-bearing deposits in a bank 
which provides extremely liberal financing to poor communities, including financing to the "community" to buy the facility.

5. Upon the occurrence of a sale of a facility, there will be no recapture of rapid amortization benefits, investment tax credits, or human investment tax credits so long as and to the extent the profits of the sale are reinvested in another similar project or in special bank deposits.

6. Following the sale of the facility to the "community," the taxpayer-seller will receive a sustained profitability tax credit which is equal to fifteen per cent of the profits generated from the operation of the facility for each of five years after sale.

Prior to any sale, a plant engaged in ghetto operations will be owned by a taxpayer who, it is assumed, will have other income. A taxpayer having other income will thus be able to utilize the tax benefits accruing prior to the sale without regard to the profitability of the facility. The rapid amortization deduction, the resurrected investment tax credit, and the new human investment tax credit-all of which operate prior to a sale of the facility - can be applied by the taxpayer against its taxable income from other sources. Carry-forward and carry-back provisions enable complete utilization of these tax benefits by the taxpayer. The question in the taxpayer's mind is what all these benefits are worth in hard dollars.

A specific example will illustrate the operation of these provisions.

In calculating dollar savings to the taxpayer, a conservative view has been taken. As indicated, tax savings take two forms. First, there is tax forgiveness through the tax credit mechanism. In this case, dollar savings are calculated as the gross amount of tax forgiven. Second, there is deferral of the collection of taxes which is achieved either by permitting accelerated deductibility or by actually delaying collection of a tax. The savings from tax deferral is calculated at seven per cent of the amount deferred. This represents either the interest charge the taxpayer would incur if he had to borrow the money to pay the deferred taxes or, if he has the money available, the interest he would earn if invested for the period of deferment.

A particular type of die casting plant can be started for approximately $\$ 600,000$. If and when profitable, it will produce pre-tax earnings of $\$ 300,000$ on gross sales of approximately $\$ 4,000,000$. Direct labor costs will run about $\$ 300,000$ per year in the casting operation, foremen's salaries will run approximately $\$ 35,000$, and indirect labor costs will be about $\$ 55,000$. Depreciable assets comprising the physical facility will have a cost basis of approximately $\$ 200,000$, representing approximately $\$ 100,000$ in equipment and $\$ 100,000$ in real estate.

Several assumptions are necessary: the plant becomes a "community" facility; the outside company which owns and operates the plant has other income and files a consolidated return and, thus, can utilize all special tax benefits available to it; and the community in which the facility is to be located is in the lowest level of economic development, thus entitling the taxpayer to the maximum tax benefits to be provided. What do the tax provisions yield in saved dollars to the taxpayer?

Rapid amortization within 36 months of real estate and equipment (total \$200,000) 
will produce annual deductions to the taxpayer of $\$ 66,666$ for each of three years. The resurrected investment tax credit of $7 \%$ applicable to section $3^{8}$ property ${ }^{6}$ will apply to the equipment in the plant $(\$ 100,000)$, yielding a direct credit against taxes payable by the taxpayer in the amount of $\$ 7,000$. The human investment tax credit will apply to the wages of those persons in the facility. Assuming that only one-half of the combined direct and indirect non-administrative wages are paid to qualified employees, a first level calculation will produce a human investment tax credit of $\$ 29,500$ (I0\% of one-half of the sum of $\$ 300,000$ and $\$$ I35,000 and $\$ 155,000$ ). If it is assumed that an annual limitation of $\$ 25,000$ is applicable to such tax credit, the maximum human investment tax credit for one taxable year of operations will be $\$ 25,000$ plus $50 \%$ of the excess, or a total of $\$ 27,250$. The $\$ 2,250$ unused excess credit for each year is not lost; it can be carried back three years or forward seven years.

Assuming consistent levels of employment and equipment utilization, the above tax deduction and credit calculations apply to each of the first three years of full operation of the facility. The savings to the taxpayer who has other income sufficient to permit full utilization of is as follows:

(I) The annual rapid amortization deduction is $\$ 66,666$. The provision speeds up the deductibility of a fixed amount, but does not increase the amount deductible. The benefit is basically one of cash flow in early years. The greater the amount deductible, the less cash will be needed to pay taxes. And at the very least, fewer dollars will be needed to cover the cost of borrowing money to pay taxes, or, if cash is available, more dollars will be earned upon investment. It should be recognized that the amount of "normal" depreciation deductions vary according to the type of asset depreciated. Likewise, land value, as such, is not depreciable. However, in order to facilitate illustration, it will be assumed that there is a combined plant and equipment life of ten years and that the amount of the yearly deduction does not vary. Under these assumptions, the normal available deduction for each of ten years would be $\$ 20,000$. On the other hand, the casting plant established under the Act may be depreciated over three years, thereby producing an extra deduction of $\$ 46,666$ per year for each of the first three years. Assuming total elimination of the surtax and one surtax exemption utilized to cover other income, the tax rate is $48 \%$. The tax due on $\$ 46,666$ is $\$ 22,400$. It is collection of this tax which is deferred to the future. When calculated at $\% \%$, the minimum dollar value of not having to pay this amount is $\$ 1570$ per year for each of three years.

(2) The investment tax credit is $\$ 7,000$. This is available in only one year, but is not subject to eventual recapture. The human investment tax credit, which is enjoyed annually, is $\$ 27,250$. An unused portion to the extent of $\$ 2,250$ may be carried forward.

Thus, the savings during the first year is $\$ 35,820$. The second and third years

\footnotetext{
${ }^{\circ}$ INT. Rev. CoDe of r954, $\$ 38$.
} 
yield a net dollar saving of $\$ 28,820$, or a total, over three years, of $\$ 93,460$. It should be emphasized that the minimum savings of $\$ 93,460$ over three years is enjoyed by the taxpayer irrespective of whether the facility is profitable. The $\$ 600,000$ investment required for the project can be highly leveraged by long term borrowings. The annual benefits, except for rapid amortization, continue to accrue to the taxpayer prior to sale.

Now assume that the facility is sold in the fourth year of operations and that the encouraged transplantation of know-how has been effective so that the facility earns a profit in the fourth year of half of its full profit potential $\$ 150,000$ before taxes. The tax rate for year four is $48 \%$ less one surtax exemption. The computation includes the tax payable upon income not matched by a depreciation deduction because all depreciation deductions were utilized in the first three years. At this point, a tax of $\$ 75$,roo is owing. The amount of net after-tax cash retained by the taxpayer is $\$ 74,900$, representing after-tax profit and depreciation adjustments.

The facility may be sold to any community group within the statutory definition on any basis which the parties are able to negotiate. Assume a classical earningsmultiple sale price formula is applied and that the multiple for this facility is xo. A critical issue is whether the specially reduced post-tax earnings of the facility which applies once the plant is in the hands of the community should be used in calculating the sale price. Normally, the multiplicand is post-tax earnings. The reason for this "normal" post-tax calculation is that the purchase price is based on payment of taxes on earnings of a facility in the hands of the acquirer. This normal rule may be applied to the casting plant with modification. When a community group is an acquirer, its tax rate will be lower than normal because of both a surtax exemption of up to $\$ 200,000$ and the lower tax rates which will be in effect when the tax becomes due.

The issue is illustrated in our example. The above model facility, when and if completely successful, will earn $\$ 300,000$ pre-tax profit per year. Assuming that the acquiring community group is in a severely underdeveloped community, taxes payable by it on such earnings can only be $\$ 3,000$ ( $\$ 300,000$ less a $\$ 200,000$ surtax exemption equals $\$ 100,000 ; 00 \%$ of the first $\$ 50,000$ and $6 \%$ of the remainder yields a $\$ 3,000$ tax).

It has been posited, however, that the model facility is sold at a time when it has reached only half its earning potential, namely $\$ 150,000$. Applying a special surtax exemption to earnings of the facility after its acquisition by the community group, no taxes will be then owing. If the sales price is negotiated on the basis of earnings at the time of sale less taxes payable on those earnings by the transferee, the earnings multiplicand will be $\$ 50,000$. Given an earnings multiple of ro, the sale price will be $\$ 1,500,000$.

If the classical multiple earnings formula for arriving at a sales price were applied to the ghetto facility, the acquiring community entity, because of its special 
low tax rates, would pass on some of its special tax benefits to the outside taxpayer in the form of a much higher purchase price. The community group would pay more money for the facility than would a private sector purchaser subject to regular tax rates, a result which is not necessarily unintentional.

The tax payable by the seller on the transaction can be computed from the sales price. Normally, the tax will be $30 \%$ of the gain plus an amount which reflects tax recaptures. Assuming that the cost of the plant is $\$ 600,000$, utilization by the taxpayer of maximum $90 \%$ leverage, and an equity basis of $\$ 60,000$, his gain is $\$ 1,460,000$, and his tax is $\$ 438,000$. It is the collection of this tax which is delayed if the taxpayer utilizes the sales proceeds to enter into another arrangement covered by the statute or if he invests the proceeds in low interest-bearing accounts in a bank which offers special loans-including the loan to buy the plant-to community groups. At the very least, the deferral of collection of such taxes can be viewed as an interest-free loan from the government, and at $7 \%$, represents actual dollar savings of $\$ 30,660$ per year. Even after the facility is sold, the outside taxpayer may have the benefit of an additional tax incentive. For each of five years following sale, the sustained profitability tax credit offsets the taxes payable by the seller to the extent of $15 \%$ of the pre-tax income of the facility. A steady profit of $\$$ I50,000 per year will produce a tax credit of $\$ 22,500$ per year, or a total credit of $\$ 112,500$ over five years.

Thus, assuming maximum leverage $(90 \%)$ is utilized by the outside taxpayer to set up the $\$ 600,000$ facility, and assuming that all facts have worked out as indicated, the taxpayer's $\$ 60,000$ investment has produced ( $I$ ) a tax benefit of $\$ 93,460$ in excess of what would be available if the facility were sited elsewhere than in the community, (2) a postponement of collection of capital gain tax of $\$ 438,000$ which is worth $\$ 30,660$ per year, (3) a sustained profitability tax credit of $\$ 22,500$ per year for each of five years following sale, (4) a capital gain of $\$ 1,460,000$ less repayment of total start-up loan of $\$ 540,000$ and less capital gain taxes of $\$ 438,000$ eventually payable, and (5) net profit less tax in year four of $\$ 74,900$. The taxpayer maximizes his benefit from the incentive over a nine year period: investment in the first year, profit by and sale of the facility in the fourth year, sale proceeds invested in tax deferral-producing investments or deposits in the fourth year with deferral of taxes upon sale proceeds until the ninth year. The net after tax cash return on the $\$ 60,000$ investment can be calculated as follows:

Investment $\$ 60,000$

Return on investment in the ninth year

Post-tax income in the fourth year of operations

$$
\begin{gathered}
\$ 1,460,000 \\
74,900 \\
(438,000) \\
-0- \\
(540,000) \\
\$ 556,900
\end{gathered}
$$$$
\text { less (I) tax on sale proceeds in year nine }
$$$$
\text { (2) recaptures }
$$$$
\text { (3) repayment of initial loans }
$$ 
plus:

(I) minimum dollar value of deductions (rapid write off, section $3^{8}$ tax credit; and human investment tax credit in the first three operating years)

(2) minimum dollar value of postponement of collection of tax on sale proceeds for five years

(3) minimum dollar value of sustained profitability tax credit

(4) carry forward or carry back of unutilized human investment tax credit

(5) minimum dollar value of absence of recaptures on rapid

write off and section $3^{8}$ tax credit assuming constant value of underlying assets (difference between ordinary income tax on $\$ 207,000$ and capital gain tax on $\$ 207,000$

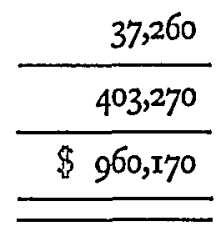

The minimum actual dollars produced by this tax incentive program are $\$ 403,270$. The amount of gain realized upon the sale of the facility is also affected by the tax results in that the sales price formula is calculated on the basis of post-tax earnings of the purchaser. The absence of taxes upon the income of the community group increases the sales price. The sales price of $\$ 1,500,000$ to the "community" was calculated at ten times earnings of $\$ 150,000$ after application of the special tax treatment afforded the community group. A non-community acquirer would pay tax in an amount equal to that payable prior to the sale. The tax on $\$ 150,000$, without the special tax incentives, would be $\$ 72,000$, yielding a sales price of $\$ 780,000$. The sale to the community increases the selling price by $\$ 720,000$. Thus, considering the minimum dollar benefits produced by this tax package, the availability of significant debt financing, and the likely sales price increase, the total dollar return induced by a facility in an underdeveloped community requiring a $\$ 60,000$ equity investment is $\$ 960,170$ net after all taxes and loan repayments.

In order to determine whether the special tax features will have the desired result of prompting taxpayer action, it is necessary to determine whether this sum is sufficient to offset the dollar cost of risks he perceives. This inquiry requires identification of the extra risks involved in setting up a facility in a ghetto. The primary risk is the cost of hiring and training the hard core unemployed. Estimates of this cost range from $\$ 1,500$ to $\$ 5,000$ per employee and include the costs of recruitment, training, and decreased productivity. If the turnover rate is $50 \%$ higher than the normal $40 \%$ rate, a $60 \%$ annual increase in the basic re-recruitment and retraining costs would be experienced. Our sample facility employs approximately r20 people, half of whom are, by assumption, considered to be hard-core un- 
employed. Assuming an average training cost of $\$ 3,000$ per worker, the cost in the first year would be $\$ 180,000$. In the second year, $60 \%$, or thirty-six, of the hard core employees will leave, yielding a second training cost $\$$ ro8,000. The same result will occur in the third year. Thus, for the first three years of operation, the extra recruitment and training costs totals $\$ 396,000$.

In light of this cost, the extra tax benefits yield conservative dollar savings of only $\$ 35,820$ in the first year and $\$ 28,820$ in the second and third years, or a total of $\$ 93,460$ for the three years. Obviously, the tax savings at this point (which accrue to the taxpayer whether or not the facility is profitable) are insufficient to meet the increased special costs of ghetto operations. It is also necessary, however, to assess the impact of attainment of profitability in the facility. On the above facts, this is achieved in the fourth year and is immediately followed by the sale of the facility to the community. If it is assumed that the facility earns an average of $\$$ I50,000 annually over the five years after acquisition by the community, the minimum dollar value of all tax savings to the taxpayer is $\$ 403,270$, an amount which is only $\$ 7,270$ in excess of the perceived extra costs.

Thus, this tax incentive program is designed to return to the taxpayer, on approximately a dollar-for-dollar basis, the extra costs involved in putting the facility into an underdeveloped community-and then only if the positive actions taken by the taxpayer produce the desired result of the transplantation of a profit-producing capital facility to a poor community.

All that has been done to this point is to attempt to offset the predictable extra costs. It is also necessary to provide a profit to cover the unpredictable, open-ended, non-business risks. The bonus lies in the purchase price for the profitable facility. As set forth above, this will exceed the price which would have been paid by a noncommunity acquirer because the community's tax load following acquisition is less. The amount of this profit is a matter of negotiation between the community and the taxpayer, subject to governmental review. The existence or amount of the profit, as it is in all acquisitions, is negotiable and as such is subject to all of the sophisticated credit techniques which can be used to "split the difference," such as increases in the purchase price following sale dependent upon increased actual earnings.

Thus, on a basis of minimum dollar savings produced by the above tax incentive package, a company which transmits its know-how and facility to the poor is made whole following a successful effort and has an opportunity to negotiate a profit for doing so. Following this successful effort, the community has acquired sixty well-paying jobs which it didn't have before, and those jobs belong to the people in the community. Further, members of the community group own a business which is actually producing $\$ 150,000$ in annual earnings. Added to this would be the 5 to I multiplier effect on new jobs produced by reinvestment of earned business profits in other ventures. 
On the other hand, if a taxpayer uses this tax package to unload out-dated facilities or fails to establish a new facility at viable profit-producing level in the competitive market, he will not benefit. Likewise, if a poor community group does not initially present to the taxpayer a stable organization, it will not attract an outside company in the first place and the desire for continuing jobs and profitability will not be satisfied.

\section{III}

\section{TAXPayer-Selected Tax Incentives}

The tax package analyzed above presents a fairly rigid scheme. It places the taxpayer in a tight factual grid in which the government's power to trade tax money for acceptance of open-ended risks comes into play with significant tax dollars only when a plant is sold to a community group. In order to qualify for the tax benefits, the taxpayer must use his money first on a roughly to to I ratio and maintain that level of expenditure for approximately four years. Moreover, he must assume the risk of being able to find a community group to purchase his plant, and he must rely on their ability, not his own, to run the plant after the sale. If any one significant event misfires, the benefits of the program evaporate and the taxpayer loses a significant amount of money. Few taxpayers would regard this tax package as overwhelmingly attractive. At best, a taxpayer would regard it as a nice gamble, and only because of the big pot of tax benefit gold at the end of a nine-year rainbow.

The policy decisions reflected in the tax package have fixed the dollar flow of tax benefits to a trickle in the early years. The tax incentive dollars produced in these years come nowhere near what the taxpayer is then paying out. As compensation for the mismatch of dollar benefits to dollar exposure in the early years, a huge tax break occurs upon sale and continued profitability of a plant. A large reward for a successful undertaking of a huge long-term risk is the basis of this tax package. But only this risk is rewarded by this tax system. A more attractive alternative incentive system may exist.

To find that alternative, it is not necessary to review a whole series of tax incentive packages and decide which one is best. An attempt to find the tax incentive package which is "best" merely compounds the error of trying to guess what incentives will encourage a taxpayer to act. By selecting one tax package which rewards only one rigid risk mix, a legislature would merely be speculating as to what will work in a highly complex and largely unexplored area. Moreover, selecting a "best" program would cancel out use of all of the imagination available in the private sector.

The task of a tax incentive program is to provide the taxpayer with a reason for doing something or, negatively stated, to minimize the risks which heretofore inhibited his desire to act. But, at the same time, a tax incentive program which is to operate in the unknown area of community economic development should not be designed or accidentally drafted in a way which dictates either the types of 
businesses to be provided or the methods of providing them. A tax incentive program which works only for highly labor-intensive investments and which does not encourage action by businesses with a reverse mix of labor and capital goods excludes industries of the future. Moreover, a program which works only if a taxpayer is willing to sell his plant to others will most likely exclude companies having proprietary products-those companies will not transfer their patents or whatever to companies which they do not control. A system which excludes from its benefits any significant type of business or which limits too greatly the method of providing meaningful career jobs to the poor may be less desirable than no incentive program at all. It is, again, over-promising. A one-track tax incentive program which freezes the kinds of economic development and narrows the methods for achieving development is especially unwanted in cases where those who develop the structure are not the businessmen who will have to take the risks.

A crucial question concerns the likelihood that a system of tax incentives for ghetto operations can be developed which will provide a taxpayer with different sets of benefits chosen by him to meet the risks he sees in a specific business opportunity. Moreover, it must be asked whether a system can be developed which will appeal to both the taxpayer who is willing to take only small risks, even at the expense of affecting the size of eventual benefits, as well as the taxpayer who is willing to assume a large risk if it would potentially yield a significant return. Of course, it is possible to permit such flexibility, and there are probably several mechanical ways to do it.

One workable multi-track community development tax incentives program would utilize all of the substantive tax incentives outlined earlier, but instead of fixing the amount of the benefit, the program would adopt several modifications. (I) The amount of the incentive would be variable within an established range. (2) The taxpayer would be permitted to choose the amount he wished to assign to a particular incentive. (3) The taxpayer could choose to attach a larger benefit to one tax incentive with the effect that this would limit the size of the benefit he could obtain under another incentive. (4) The total amount of benefits chosen by the taxpayer would be controlled by use of a limitation expressed in terms of either dollars or points assigned to particular benefits.

A simple example will illustrate the effect of this type of multi-track tax incentive program. The program which included the following benefits might utilize the following value allocation: ${ }^{7}$

I. Rapid write off of physical facilities.

(a) Write off covering the physical plant but not real estate. (i) in 36 months $-X$ points

\footnotetext{
${ }^{7}$ The use of the symbol $X$ instead of a number is intentional. By doing so, a discussion of the value of any particular incentives is postponed until a detailed system is worked up and tried out. What is important now is the principle of and experimentation with a taxpayer's choice incentive system.
} 
(ii) in 30 months $-X$ plus 2 points

(iii) in 24 months $-X$ plus 4 points

(b) Write off of both physical facility and real estate

(i) in 36 months $-X$ points

(ii) in 30 months $-X$ plus 2 points

(iii) in 24 months $-X$ plus 4 points

2. Physical facility investment tax credit.

at $7 \%-X$ points

at $8 \%-\mathrm{X}$ plus 2 points

at $9 \%-\mathrm{X}$ plus 4 points

at $10 \%-X$ plus 6 points

3. Human investment tax credit.

at $10 \%-\mathrm{X}$ points

at $\mathrm{Ir} \%-\mathrm{X}$ plus 2 points

at $12 \%-X$ plus 4 points

at $13 \%-X$ plus 6 points

4. Postponement of capital gain on sale; non-re-capture in event of sale; sustained flexibility tax credit effective after sale.

(a) If elected-X plus 20 points

(b) If not elected, then double the amount of benefits otherwise elected may be chosen

A multi-track incentive system, such as that suggested above, would permit the taxpayer to select a package of tax incentives tailored to: (a) the precise type of business which the taxpayer is considering for ghetto operation, (b) the peculiar risks he perceives in the project, and (c) a flow of tax benefits in which the amount and timing of the tax advantage is inversely proportionate to the risks accepted by the taxpayer. For example, a taxpayer considering labor intensive operation which requires a relatively small investment in physical facilities would choose the highest human investment tax credit available. He would not be particularly concerned about tax benefits relating to physical facilities whether such tax benefits took the form of rapid right-offs or physical facility investment credits. By selecting the highest possible percentage of human investment tax credit, he would not only be selecting a benefit with particular application to his business, but he would have also decided that he wanted the cash flow resulting from the selected tax benefit to match as closely as possible the time at which he is required to spend money on the hard core unemployed. The human investment tax credit is an example of partial tax forgiveness which occurs in the year of the qualifying expenditure, rather than at some later time at which the risk of the occurrence of some event must be accepted by the taxpayer. Because the human investment tax credit is available in the year 
of expenditure and is available to the taxpayer upon the occurrence of an event controlled by him, namely paying his hard core employees, he not only has selected a tax benefit which applies to his kind of business and received the benefit in the year he paid his money; but he has also made receipt of the benefit a certainty, or at the very least, highly predictable. In exchange for receiving tax benefits concurrently with the expenditures which produce them, the taxpayer gives up a larger tax benefit contingent upon future events which would have subjected him to more risk. If the tax package of the Community Self-Determination Act is based upon a policy of providing a taxpayer with a large reward for undertaking a large risk, the tax incentives selected by the taxpayer in this example show the operation of a tax system which exchanges a smaller tax benefit for a smaller risk.

Under a flexible system, there are legion combinations of tax benefit packages which can be designed by a taxpayer for his specific operation to compensate for the number, type, and degree of risks he is willing to accept. The permutations available under a multi-track tax incentive program are exactly what is required to encourage the experimentation necessary to provide evidence of the type of incentives which actually encourages private sector investment in the ghetto. It is only at this pointthe point in time when the evidence is in-that will be possible to determine which combination of incentives, if any, were successful and, then, whether the government got its money's worth.

\section{IV}

\section{Should Tax Incentrves Be Used At All?}

Many thoughtful men in government, in law schools, and elsewhere have spent much time and effort considering the viability of tax incentives as a means of encouraging taxpayer action. Opinion differs widely. Some take the position that utilization of tax incentives is a misuse of the taxing power, a distortion of the symmetry of the Code, and an evil which provides the opportunity to achieve artificial transactions in order to benefit the rich who are fortunate enough to be able to hire tax advisers. Others suggest that a new start be made with the tax code and that we reduce the tax rate significantly and eliminate all of the gimmicks. Although over one thousand pages of tax code may not be a desirable thing, it does exist, and it is the author's view that this should be dealt with as it is, not as it might have been.

Unbridled faith in the utilization of tax benefits is a position taken by others. It is true, for example, that the use of a 10\% tax credit achieves the result of having a taxpayer spend $\$ 9$ for every dollar the government is willing to spend to achieve certain action. Obviously, this represents a first level $\$ 9$ savings to the government if it were in the position to spend the \$Io in the first place. There are very few who would suggest the multiplier effect resulting from the use of incentives is not an important factor to consider. 
It does seem, however, that there may be certain risks for the private sector in community economic development which cannot be solved by tax incentives, no matter how big they are, no matter how much taxpayer choice there is, and no matter how lenient the Internal Revenue Service is willing to be on audit. It has been pointed out that incentive legislation enables the government to exercise its power to either reduce risks or trade incentives for acceptance of unmeasurable risks which currently inhibit desired action by the private sector. To the extent that a risk is a business risk-that is, one which is calculable in dollars and of a type familiar to the taxpayer-tax or other fiscal incentives are probably applicable. On the other hand, if a risk is a non-business nature-unmeasurable by application of currently available business skills-one ought to have second thoughts about using tax benefits to overcome it.

For example, a non-business risk which appears to be in the minds of many businessmen is the fear that their plant, whether in the ghetto or elsewhere employing the hard core unemployed, will become the subject of a political or social dispute. This is the kind of risk which businessmen do not know how to measure. And worse, they find it difficult to sense the occurrence of an innocent appearing set of facts which might give rise to a situation in which their plant becomes a pawn in a social battle. The tax incentive designed to meet this problem would, in effect, become income interruption insurance. A total loss coverage tax incentive would never become law. But this problem may be the proper subject of a special government insurance program in which private sector insurance companies develop a pooled risk program with government participation.

The risk that a plant may become involved in a political dispute is not a new problem to American businessmen who have operated overseas in underdeveloped nations. In such cases of overseas economic development, the risks of war and civil disturbance are often present to varying degrees. Congress approached this problem years ago, and legislation was created to meet the risks preceived by American businessmen. ${ }^{8}$ Under an investment guarantee program an American company could buy "political risk insurance" from the government which covered some of the risks of war, rebellion, and civil commotion. It was provided that the insurance would not be available unless it was the very issuance of a guarantee which "encouraged" the company to make the investment. Thus, the legislation creating the investment guarantee program specifically acknowledged that it could be used only by a company which was otherwise unwilling to act because of its perception of certain risks. It is not suggested, however, that the foreign investment guarantee program could be applied directly to business activities in domestically underdeveloped areas. The analogy is not sufficiently complete to permit the transposition.

The example should indicate that it is possible to develop a workable incentive system which would offset measurable business risks. But it seems equally clear that

\footnotetext{
${ }^{8}$ Foreign Assistance Act of I96I, 22 U.S.C. $\$ 235$ I (I964).
} 
tax incentives cannot offset certain risks of a non-business nature which cannot be measured in dollars and the occurrence of which cannot be successfully forecasted. A program combining a multi-track tax incentive program and a "domestic investment guarantee program" should be developed. If successful, it would likely be cheaper, from the government's point of view, than either the undertaking of community economic development by the public sector or the symptomatic control of the social problems of the ghetto by expanded police and riot control forces.

\section{$\mathrm{V}$}

\section{A Nobie EXPERIMENT}

If a program involving a multi-track taxpayer's choice tax incentive system and an investment guarantee insurance pool (or insurance company tax incentives) is to be tried, it seems that Congress is entitled to some evidence that such program will work before it legislates such matters into the Internal Revenue Code. The current fad is to develop "models." It is always possible to select facts, select a group of tax incentives, and program a computer so that it will apply such facts and incentives to each other in order to produce pro forma or actual operating financial statements of a "model" company and "model" tax returns to show what would happen if a particular "model" program would have been in effect at the time. Even this much is helpful because it is more than has been done before. However, computers are only able to add, subtract, multiply, and divide; they are not able to judge. An artificial attempt to computerize unquantified risks in an unexplored area is a guess on a print-out sheet; nothing more. Indeed, such an attempt is nothing more than what was done in part II of this article and both efforts are subject to criticism if they are represented as anything more than guesses. A great deal more experimentation is required than can be provided by a nude computer or law review articles. Only by intentionally introducing the human element into the equation is it possible to provide a sampling of actual taxpayer use of incentives. And it is only that kind of evidence which ought to justify the creation of new sections in the tax code or the creation of a government insurance program of the type which will work.

I suspect that somewhere in the federal government there are funds available to actually simulate the effect of tax and/or insurance incentives on more than a six month or one year basis and that there is someone in the government to decide which agency or inter-agency pidgeon hole should receive the project. The mechanics are not the issue, for the success of the experiment depends on other factors. The question is not so much the availability of funds to simulate such a program, or the style of the simulation, but, as is true in most cases, the key is the human beings who administer such a program. We are dealing with questions of taxes. We are dealing with business people and we are dealing with a relationship of a taxpayer to the Internal Revenue Service and to eventual audits performed by it. 
It seems that an attempt to experiment with possible tax laws before they become laws would have its best chance of being successful if guided by the toughest, most suspicious, no-nonsense tax specialists and hard-line Revenuers the government has in its shop. If nothing else, this would at least make people available who can speak a businessman's language. But there is something else: having tax people in the act minimizes the very human bias which propels any man to sink a project if he, the expert, was not in on it in the first place.

This is not to say that the Office of Economic Opportunity or the Model Cities office or parts of the Commerce Department or parts of the Labor Department or, indeed, counselors or advisers at the White House should not get involved in such programs. They are all, in one way or another, in the poverty business; and since tax incentives or an insurance program are designed to add an additional tool for the achievement of their goals, it would certainly be a mistake to exclude such people. To formulate and to simulate tax incentives without tax people, however, would invite disaster.

Tax experts know that if the problem were to aid the growth of a specific industry, there would be a half-century of tax incentive tradition and evidence available so that exhaustive experimentation would not be necessary. In such cases, the analysis would be carried along within predictable and acceptable lines emanating from a defined and proven source. But the task faced now is to aid any kind of business, not as an end in itself, but as a means to provide a self-supported future to poor people. This task assigned to tax incentives is new in this country, without tradition and without factual evidence of its viability. The work done now is the source. The issue is: the source of what? The thinking, the testing, and the theories we struggle with are more than games for the amusement of lawyers and professors. To experiment is to produce evidence, and a simulation may produce a method, other than welfare, to help change the grim reality which makes life so brutalizing for so many. Of course, the evidence may point the other way. If the end result of the simulation is that neither tax incentives nor insurance programs will encourage private sector participation in poverty areas, so be it. At least we will have tried something useful and we will know more then than we know now. 